\title{
Research Trends on the Longitudinal Studies of Childhood Stuttering
}

\author{
Soo Bok Lee ${ }^{\mathrm{a}}$, Hye Yeon Park ${ }^{\mathrm{b}}$, Hyun Sub Sim ${ }^{\mathrm{b}}$ \\ ${ }^{a}$ Department of Speech-Language Therapy \& Aural Rehabilitation, Woosong University, Daejeon, Korea \\ ${ }^{b}$ Department of Communication Disorders, Ewha Womans University, Seoul, Korea
}

Correspondence: Hyun Sub Sim, PhD Department of Communication Disorders, Ewha Womans University, 52 Ewhayeodae-gil, Seodaemun-gu, Seoul 03760, Korea Tel: $+82-2-3277-2120$

Fax: +82-2-3277-2122

E-mail: simhs@ewha.ac.kr

Received: April 7, 2019

Revised: May 19, 2019

Accepted: June 3, 2019

This study was supported by the research fund of the Ministry of Education of Korea and National Research Foundation of Korea in 2018 (No. NRF-22018-1600-001-1).
Objectives: The purpose of this study was to review research trends for longitudinal studies of children who stutter (CWS) and to provide evidence-based directions for longitudinal research and Smart Device for Utterance Analysis (SDUA) application. Methods: Included articles were published 1990-2018 in domestic journals (Communication \& Sciences Disorders and Journal of Speech-Language \& Hearing Disorders) and international journals (Journal of Speech, Language, and Hearing Research and Journal of Fluency Disorders). Results: Twenty-eight articles that met the criteria were chosen. The results showed that 12 articles (42\%) compared CWS with CWNS (children who do not stutter), or a CWS recovery group with a persistence group. Eight articles (29\%) studied treatment and 8 articles (29\%) identified characteristics of CWS. In terms of participants, 3 articles (11\%) included children under 1 years old, and 25 articles (89\%) included children between the ages of 2 and 6 . In regards to the method of research, the majority of treatment-comparison research examined the between group differences, and characteristic research examined both between and within group differences. In domestic articles, the research was mostly conducted over 18 months, and in international articles, the research was mostly conducted for 24 months. In treatment-comparison research, between 11 and 20 participants were included in domestic articles, and between 21 and 50 participants in international articles. Characteristics research included over 100 participants (44\%). The dependent variables mostly were examined utterance analysis for change. Conclusion: The majority of longitudinal studies measured more than two dependent variables for more than 6 months of research. This study demonstrated that all research was following evidence-based treatment. The SDUA application was found to measure the child's language and speech characteristics, parental characteristics, and to collect and analyze longitudinal data.

Keywords: Childhood stuttering, Longitudinal studies, Fluency disorders, Research trends, SDUA
말더듬은 대부분 언어발달이 급속도로 이루어지는 시기인 2세 이후에 시작이 되며, 말더듬이 시작된 아동들의 $75 \%-85 \%$ 는 치료 적인 도움 없이 7 세 이전에 자연회복되고, 나머지 $15 \%-25 \%$ 는 지속 된다고 한다(Yairi \& Ambrose, 2005, 2013). 말더듬이 지속되는 아 동들의 경우 사회성 발달(Van Borsel, Brepoels, \& De Coene, 2011) 이나 학업에 어려움을 겪거나(O’Brian, Jones, Packman, Menzies, \& Onslow, 2011) 놀림을 받기도 한다(Lee, Lee, Sim, \& Oh, 2016). 말 더듬이 지속되면서 발생할 수 있는 위와 같은 문제점들을 줄이기
위해서는 말더듬의 진전에 영향을 미치는 요인들에 대한 연구와 이 해가 필요하다. 최근까지 말더듬의 회복과 지속에 기여하는 요인이 무엇인지 찾기 위한 다수의 연구들이 진행되었으며, 많은 연구자들 은 말더듬의 발달과 여러 다양한 요인들과의 관련성에 대해 설명하 고자 하였다(Chon \& Ambrose, 2016; Erdemir, Walden, Jefferson, Choi, \& Jones, 2018; Lee \& Sim, 2016; Yairi \& Ambrose, 2005). 이들 요인에는 말 실행능력, 언어 및 인지능력, 심리적 요인, 환경적 요인 등이 보고되고 있는데, 아직까지 말더듬의 회복과 지속에 영향을 
미치는 원인이 무엇인지에 대해서는 명확히 밝혀지지 않았다.

말더듬의 회복 및 지속요인들에 관한 연구에 의하면 말더듬 발 달에 다양한 요인들이 상호작용하며, 이러한 요인들 간의 상호 영 향력은 시간이 지남에 따라 달라질 수 있다고 주장한다(Smith \& Kelly, 1997). 연구자들은 시간이 경과함에 따라 변화하는 요인들 의 영향력을 알아보기 위해서 주로 종단연구 방법을 사용한다. 종 단연구는 연구기간이 길기 때문에 실시하기 어려운 단점이 있으나, 시간의 흐름에 따른 변화를 살펴보는 데 매우 효과적인 방법이다. 한편, 횡단연구는 고정된 한 시점을 기준으로 연구가 진행되기 때 문에 말더듬을 회복과 지속으로 이끄는 잠재적인 요인을 놓칠 수 도 있다는 한계가 있다.

말더듬 발생 이후의 누적된 말더듬의 경험이 구어-운동 실행능 력, 언어능력, 인지능력, 감정 등과 같은 말더듬의 회복과 지속에 관 련된 예측요인들에 영향을 미치기 때문에(Erdemir et al., 2018) 예 측요인들에 관한 연구들은 주로 말더듬이 시작되는 시기인 취학전 아동을 대상으로 한다.

취학전 아동들을 대상으로 한 종단연구는 1980년대에 Yairi의 연구팀들에 의해 소규모로 시작되었다. Yairi와 동료들은 비유창성 특성에 대한 종단연구를 계속적으로 실시하였는데, 어린 아동들 의 말더듬 발생(Yairi, 1983), 2-3세 일반아동의 비유창성 특성(Yairi, 1981,1982 ), 말더듬 발생시기에 따른 비유창성 특성(Yairi \& Lewis, 1984), 말더듬 지속 및 회복집단의 비유창성 특성(Yairi \& Ambrose, 1999) 등의 연구를 진행하였다. 비유창성 특성에 대한 일련의 종단 연구는 초기 말더듬아동을 일반아동의 비유창성과 구분할 수 있 는 비유창성 유형을 밝혀내고자 하였으며, 말더듬이 지속되는 요인 을 예측할 수 있는 근거자료가 되었다. 최근에는 비유창성 특성뿐 만 아니라, 언어 및 조음음운능력과 같은 특성연구도 진행되어 언 어능력과 초기 말더듬과의 관계에 대한 고찰이 이루어졌으며(Am-

brose, Yairi, Loucks, Seery, \& Throneburg, 2015; Usler, Smith, \& Weber, 2017; Watts, Eadie, Block, Mensah, \& Reilly, 2017), 말더듬 아동의 심리적 측면에 대한 특성연구도 이루어지고 있다(Ambrose et al., 2015; Kefalianos et al., 2017a; Kefalianos, Onslow, Ukoumunne, Block, \& Reilly, 2017b; Smith et al., 2017).

또한, 말더듬아동의 중재효과를 다룬 실험논문들이 종단연구의 다수를 차지하고 있다. 많은 연구자들이 중재효과를 알아보기 위 해 종단연구를 선택하는 이유는 치료가 종결된 이후에도 지속적 이고 안정적으로 유지가 되고 있는지를 평가해야 하기 때문이다. 중재효과를 살펴보기 위한 종단연구를 실시하는 연구자들은 대조 군과의 비교를 통해 특정 말더듬 치료법의 효과를 검증할 뿐 아니 라, 말더듬 치료의 효과를 보기 위해 말더듬 아동과 부모의 말속도,
발화길이, 모음지속시간, 의사소통태도 등과 같은 요인에 대한 분 석을 통해 말더듬아동의 변화 특성을 설명하고자 하였다(Lee \& Sim, 2015, 2016, 2017; Millard, Nicholas, \& Cook, 2008; Riley \& Ingham, 2000; Trajkovski et al., 2009; Park, Lee, \& Sim, 2015).

전술한 특성 및 중재효과를 알아보고자 한 대다수의 실험논문 들은 대조군과 비교하는 방법을 사용하고 있었다. 예를 들면, 말더 듬아동을 일반아동과 비교하거나, 말더듬아동을 회복과 지속집단 으로 나누어 비유창성 빈도 및 유형, 언어 및 조음음운능력, 말속 도, 말더듬에 대한 인식 및 태도, 부모요인 등을 비교하였다(Buhr \& Zebrowski, 2009; Hall, Amir, \& Yairi, 1999; Hilger, Zelaznik, \& Smith, 2016; Kloth, Janssen, Kraaimaat, \& Brutten, 1998; Kloth, Kraaimaat, Janssen, \& Brutten, 1999; Paden, Ambrose, \& Yairi, 2002; Ryan, 2001; Throneburg \& Yairi, 2001; Wagovich, Hall, \& Clifford, 2009; Yairi \& Ambrose, 1999). 이러한 비교연구들은 장애 군 집단과 대조군 집단 간에 차이를 보이는 변인들을 파악함으로 써 장애군과 대조군을 구분하는 변별적 특성을 밝히고자 하였다.

말더듬아동을 대상으로 한 종단연구들을 종합해 보면, 말더듬 의 하위분류(subtype), 말더듬 유형 및 빈도, 말더듬아동의 기질이 나 성격 등의 특성, 말더듬아동의 언어발달 및 조음음운능력, 그리 고 치료 효과와 관련된 연구들로 분류될 수 있다(Buhr \& Zebrowski, 2009; Hall et al., 1999; Kloth et al., 1998, 1999; Ryan, 2001; Throneburg \& Yairi, 2001; Yairi \& Ambrose, 1999).

말더듬 치료와 관련하여 증거기반의 치료(evidence-based practice)에 대한 관심과 필요가 증가함에 따라, 장기적으로 말더듬 치 료 효과를 검증하고 말더듬 회복을 예측하는 요인을 찾아내려는 연구들이 필요하다. Bloodstein과 Bernstein Ratner (2008)는 유창 성장애의 치료 효과를 논할 때 증거중심의 치료 관점에서 다음과 같은 사항들이 고려되어야 한다고 했다. 실험군과 대조군의 대상자 수가 충분했는지, 말더듬 빈도 또는 중증도가 객관적으로 측정됐 는지, 그리고 치료 효과가 반복적으로 평가되었는지를 보아야 하 며, 그리고 그 치료 효과가 18 개월에서 2 년 정도 지속되어야 적절하 다고 제시하고 있다. 나아가 적절한 대조군이 비교되었는지, 치료 실 내에서 확립된 치료 효과가 치료실 밖에서도 전이되었는지 또는 다양한 상황에서 전이되었는지를 확인해 보아야 한다. 그러나 현재 까지 진행된 연구들은 특정 말더듬 프로그램의 효과를 검증하고 유창성 확립에 얼마나 기여하는지에 대한 설명이 주를 이루었고, 실제 장기적인 관점에서 치료의 효과와 아동의 변화를 설명한 종 단연구들에 대한 문헌연구가 부재하다. Shin, Chon과 Lee (2009) 의 연구에서 2000-2009년까지의 국내외 말더듬 치료와 관련된 문 헌연구는 이루어졌으나, 말더듬아동을 대상으로 한 종단연구는 부 
재한 실정이다.

취학전 말더듬아동의 연구에서는 고려해야 할 발달적인 요소들 도 많고 가변성이 높아 아동들의 정확한 수행력을 단기간에 파악 하기에 어려움이 많고, 시점별로 다른 결과를 도출해낼 수 있으므 로 장기간 그리고 지속적 측정이 필요하다. 발전된 기술을 활용하 여 자동화시스템을 구축하면 종단연구의 어려움을 줄이고 많은 대상자의 데이터를 쉽게 수집하고 분석할 수 있다. 한국연구재단의 연구지원을 받아 개발 중인 자동발화분석 앱(Smart Device for Utterance Analysis, SDUA)은 아동의 말더듬 및 언어발달 특성, 그리 고 부모특성들의 변화를 측정할 수 있는 자동화 분석시스템이다. 이 시스템을 활용하면 장기간 아동의 말, 언어특성 그리고 부모의 영향을 파악하여 한국형 종단적 말더듬아동 진단 및 치료에 적용 할 수 있는 데이터를 구축할 수 있다.

따라서 본 연구는 최근 30년간 말더듬아동을 대상으로 한 국내 외 종단연구를 조사하여 국내외 연구의 추이를 살펴, 향후 종단연 구와 SDUA 앱의 방향 및 필요성을 제시하고자 한다. 이를 위해 본 연구에서는 학령전기 말더듬아동을 대상으로 한 국내외 종단연구 가운데 연구기간이 6개월 이상인 연구를 선정하여 중재, 특성, 비 교연구로 분류하여 살펴보고자 한다. 중재의 효과를 다룬 논문뿐 만 아니라, 중재와 관련된 말더듬아동의 특성연구, 대조군과의 비 교연구를 포함하여 확인하고, 말더듬아동의 특성연구, 일반아동 과 대조군(지속집단 및 회복집단)을 비교한 비교연구를 검토하여 말더듬아동의 특성, 말더듬이 회복된 아동과 지속된 아동의 다른 점에 대해 살펴보고 이를 통해 말더듬의 회복과 지속에 영향을 미 치는 요인들의 관련성에 대한 정보를 제공하고자 한다.

\section{연구방법}

\section{분석기준}

국내외 말더듬아동 종단연구의 논문 선정기준은 다음과 같고 선정 절차를 도식화하여 Figure 1에 제시하였다.

(1) 발표연도: 최근의 초기 말더듬 종단연구와 관련 있는 연구의 동향을 보기 위하여 1990-2018년(12월까지)에 등재된 논문으 로 선정하였다.

(2) 학술지 선정: 유창성장애 분야의 권위있는 학술지인 국내의 한국언어청각임상학회의 Communication \& Sciences Disorders (CSD)와 한국언어치료학회의 Journal of Speech-Language \& Hearing Disorders (JSLHD), 그리고 국외의 Journal of Speech, Language, and Hearing Research (JSLHR), 그리 고 Journal of Fluency Disorders (JFD) 내에서 논문을 선정하

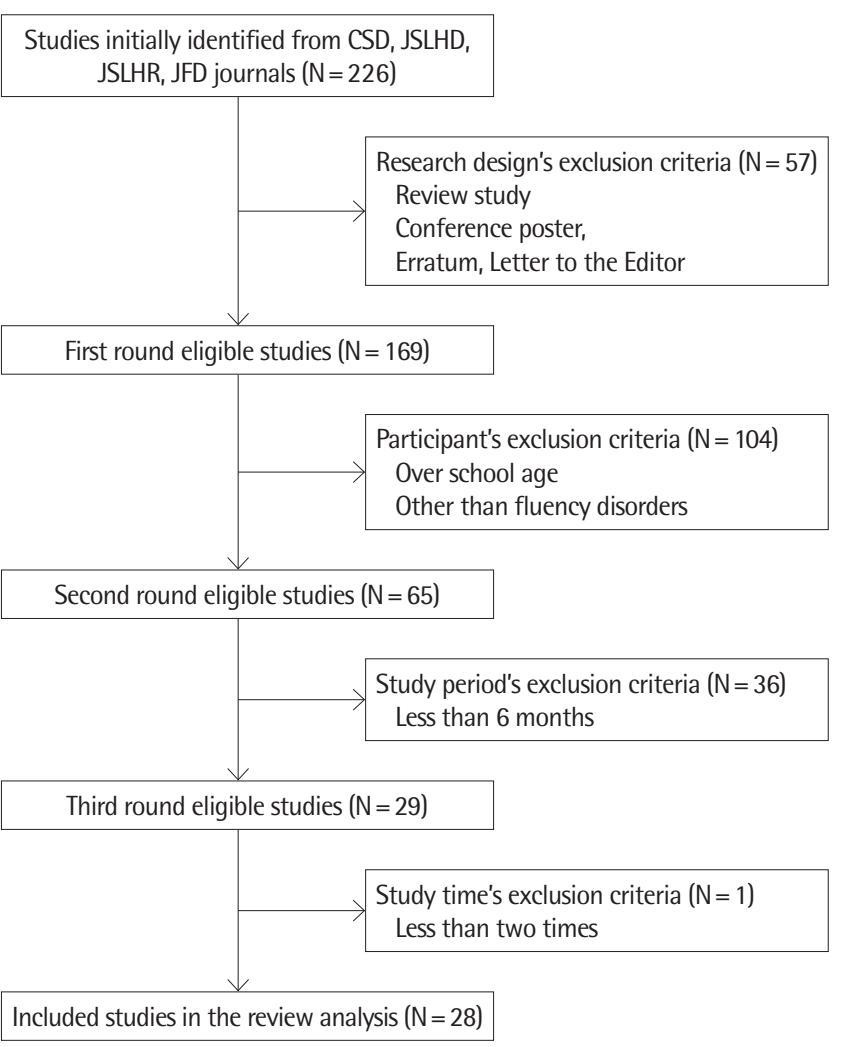

Figure 1. Flowchart of studies included from database search. CSD $=$ Communication \& Sciences Disorders; JSLHD = Journal of Speech-Language \& Hearing Disorders; JSLHR= Journal of Speech, Language, and Hearing Research; JFD = Journal of Fluency Disorders.

였다. 4 개 학술지에서 기간 내에 검색된 종단연구 논문은 총 226편이었다.

(3) 연구형태: 말더듬아동의 중재효과를 6개월 이상 다룬 중재연 구, 말더듬아동의 특성을 다룬 특성연구, 혹은 말더듬회복아 동과 말더듬지속아동, 일반아동 집단을 비교한 비교연구를 분석 하였다. 또한, 실험연구만을 포함시켰으며 문헌연구, 학 회 포스터, 오류수정, 편집자에게 보내는 편지는 제외한 결과, 57 편이 제외되어 169 편의 논문이 1 차 선정되었다.

(4) 연구대상: 취학전 말더듬아동을 대상으로 한 연구만을 포함시 켰다. 연구시작 시점에는 학령전기였으나 종단연구 기간 동안 학령기가 된 연구는 포함하였다. 말더듬아동과 일반아동의 비 교 논문일 경우, 일반아동은 말더듬아동과 말더듬 외의 조건 을 통일시킨 연구를 선정하였다. 학령기 말더듬아동 연구를 제 외한 결과, 104 편이 제외되어 65 편의 논문이 2 차 선정되었다.

(5) 연구기간: 연구기간은 최소 6개월 이상인 연구를 선정하였으 며, 단일대상 연구인 경우 기초선, 유지단계를 포함한 연구기 간이 6개월 이상인 연구는 포함하였다. 6 개월 미만인 연구를 
제외한 결과, 36 편이 제외되어 29 편의 논문이 3 차 선정되었다.

(6) 연구주기(횟수): 동일한 변인을 수집한 연구주기(횟수)를 조 사하였으며, 2 회 이상의 데이터를 제시한 연구를 포함하였다. 1 회의 데이터 수집을 한 연구를 제외한 결과, 1 편이 제외되어 28편의 논문을 최종 선정하였다.

\section{분석방법}

\section{연구형태 분석}

연구형태는 관찰방법에 따라 중재연구, 특성연구, 비교연구로 연 구유형을 분류하였다. ‘중재 및 비교' 또는 ‘비교 및 특성’처럼 중복 형태 논문의 경우 ‘중재 및 비교’ 논문은 ‘중재’로, ‘비교 및 특성' 논 문은 '특성'으로 분류하여 전체 논문수는 유지하면서 연구형태별 수치를 파악하고자 하였다.

\section{중재연구}

말더듬아동 치료기법 및 도구를 사용하여 말더듬 치료 효과를 종단적으로 연구한 논문들을 분류하였다. 여러 가지 말더듬아동 치료기법을 사용하여 말더듬 치료 효과를 비교한 논문들도 포함 하였다.

\section{특성연구}

말더듬아동의 말더듬 시작특성, 발화특성, 상황에 따른 핵심행 동의 변화, 부수행동의 특성, 말더듬과 말더듬 치료에 관한 인식, 혹 은 기질적 특성을 연구한 논문들을 분류하였다. Cohort 집단연구 는 특성연구에 포함되었다.

\section{비교연구}

말더듬아동과 일반아동의 발화특성, 기질적, 말더듬 인식 등의 집단 간 차이를 연구한 논문들이 비교연구에 포함되었다.

\section{연구대상 분석}

연구대상은 연구에 참여할 시점의 연령에 따라 분류하였다. 학 령전기 아동들을 대상으로 하여 1세 미만 아동, 2-6세 아동 대상의 연구로 분류하였다.

\section{실험절차 분석}

비교집단 및 집단특성

연구형태별로 비교집단(집단 내 비교, 집단 간 비교, 집단 간·집 단 내 비교, 단일대상연구)과 집단 특성(말더듬회복집단, 말더듬지 속집단, 말더듬집단, 통제집단)을 분석하였다.
연구의 기간, 주기, 횟수

연구의 기간: 6 개월 이상 연구의 경우 종단연구를 대상으로 하여 $6-11,12,18,24,36,48,60$ 개월 이상으로 나누어 분석하였다.

연구의 주기 및 횟수: 동일한 변인을 수집한 시간적 주기를 조사 하였으며, $1,3,6,12$ 개월, 24 개월 등으로 나누어 분석하였다. 또한 변인마다 데이터를 수집한 횟수를 조사하여 2 회 이상, 3,4 회 등으 로 분석하였다.

연구대상자수

연구대상자 수를 1-10, 11-20, 21-50, 51-80, 81-100, 101명 이상으 로 나누어 분석하였다.

\section{종속변인 분석}

중재연구, 특성연구 및 비교연구에서의 종속변인은 아동의 발화 특성, 기질적 특성, 말더듬 및 치료에 대한 인식.수반행동, 부모특 성의 4 영역으로 분류하였다.

발화특성

비유창성의 특성(비유창성 유형 및 빈도, 말더듬 비율[\%SS: percentage of syllables stuttered] 및 말더듬 중증도)와 그 외의 발화패 턴의 변화를 측정한 연구들(예: 말속도, 말의 자연스러움, 조음운 동능력, 운동능력, 모음지속기간 등)을 포함하였다.

\section{기질적 특성}

중재연구는 치료를 통한 기질적 변화를 측정한 연구들이 포함되 었다. 특성 및 비교연구는 말더듬아동의 기질적 특성을 연구하거 나, 말더듬아동과 일반아동의 기질적 차이를 비교한 논문들을 포 함하였다.

말더듬, 말더듬 치료에 대한 인식·수반행동

중재연구는 말더듬 치료를 통해 아동이 말더듬에 대한 태도나 수반행동이 변화되었는지를 측정한 연구들이 포함되었다. 특성 및 비교연구는 말더듬아동들이 가지고 있는 말더듬과 말더듬 치료에 대한 인식이나 부모의 평가를 연구한 논문들을 포함하였다.

\section{부모특성}

부모관련 종속변인(부모의 의사소통행동, 반응시간, 조음속도 등)이 포함되었다. 
독립변인 분석

독립변인은 치료접근 요인을 분석하였다.

\section{연구결과}

\section{분석논문 수치 결과}

본 연구의 선정기준에 부합하여 포함된 논문은 총 28 편으로, CSD 3편, JSLHD 2편, JSLHR 12편, JFD 11편이다. 선정된 논문에 대한 자세한 정보는 Appendix 1에 제시하였다. 학술지의 연도별 논 문 편수는 Table 1과 같다.

\section{분석방법 결과}

\section{연구형태 분석}

‘중재 및 비교’ 논문은 중재로, ‘비교 및 특성' 논문은 특성으로

Table 1. Number of papers published by year

\begin{tabular}{|c|c|c|c|c|c|}
\hline & \multicolumn{2}{|c|}{ Domestic } & \multicolumn{2}{|c|}{ International } & \multirow{2}{*}{ Total } \\
\hline & CSD & JSLHD & JSLHR & JFD & \\
\hline 1990-1994 & & & & & 0 \\
\hline 1995 & & & & 1 & 1 \\
\hline 1996 & & & & & 0 \\
\hline 1997 & & & & & 0 \\
\hline 1998 & & & & 1 & 1 \\
\hline 1999 & & & 2 & 1 & 3 \\
\hline 2000 & & & 1 & & 1 \\
\hline 2001 & & & 1 & 1 & 2 \\
\hline 2002 & & 1 & 1 & & 2 \\
\hline 2003 & & & & & 0 \\
\hline 2004 & & & & & 0 \\
\hline 2005 & & & & & 0 \\
\hline 2006 & & & & & 0 \\
\hline 2007 & & & & & 0 \\
\hline 2008 & & & 1 & & 1 \\
\hline 2009 & & & & 3 & 3 \\
\hline 2010 & & & 1 & & 1 \\
\hline 2011 & & & & & 0 \\
\hline 2012 & & & & & 0 \\
\hline 2013 & & & & & 0 \\
\hline 2014 & & & & & 0 \\
\hline 2015 & 1 & 1 & & 1 & 3 \\
\hline 2016 & 1 & & 1 & & 2 \\
\hline 2017 & 1 & & 4 & 1 & 6 \\
\hline 2018 & & & & 2 & 2 \\
\hline Total & 3 & 2 & 12 & 11 & 28 \\
\hline
\end{tabular}

CSD = Communication \& Sciences Disorders; JSLHD = Journal of Speech-Language \& Hearing Disorders; JSLHR= Journal of Speech, Language, and Hearing Research; $\mathrm{JFD}=$ Journal of Fluency Disorders.
연구형태를 분석한 결과, 집단 간 비교한 비교연구논문 12 편(42\%), 중재연구논문 8편(29\%), 말더듬아동의 특성을 연구한 특성연구논 문 8편(29\%) 순으로 나타났다(Table 2).

\section{연구대상 분석}

연구대상을 연구에 참여한 시점의 연령으로 분류한 결과, 학령 전기 아동의 연령을 더 상세히 분류해 보면 1 세 미만 아동 연구가 3 편(11\%), 2-6세 아동을 대상으로 한 연구가 25편(89\%)으로 나타났 다(Table 3).

\section{실험절차 분석}

비교집단 및 집단특성

국내외 종단 중재연구와 특성 및 비교연구 논문들의 비교집단 및 집단특성 유형은 Table 4 와같다.

중재 및 비교, 비교연구: 국내외의 중재 및 비교, 비교연구를 실험 절차에 따라 분류한 결과, 국내 연구는 집단 간 치료 효과를 비교한 연구가 4편(80\%)으로 가장 많았으며(예: Lee \& Sim, 2015, 2016, 2017; Park et al., 2015), 개인 중재효과를 제시하기 위한 단일대상연구는 1편(20\%; 예: Jung \& Kwon, 2002)으로 나타났다.

국외 연구는 집단 간 치료 효과를 비교한 연구가 10편(66\%)으로 가장 많았으며(예: Hall et al., 1999; Kloth, Janssen, Kraaimaat, \& Brutten, 1995; Kloth et al., 1998, 1999; Paden et al., 2002; Riley \& Ingham, 2000; Ryan, 2001; Sawyer \& Yairi, 2010; Throneburg \& Yairi, 2001; Yairi \& Ambrose, 1999), 집단 내 2편(13\%; 예: Buhr \& Zebrowski, 2009; Wagovich et al., 2009), 단일대상연구 2편(13\%; 예: Millard et al., 2008; Trajkovski et al., 2009), 집단 내·집단 간 비 교한 연구가 1편(6\%; 예: Hilger et al., 2016)으로 나타났다.

특성 및 비교연구, 특성연구: 국내외의 특성 및 비교, 특성연구를 연구절차에 따라 분류한 결과, 국내에서는 해당 연구가 없었다. 국 외의 경우, 총 8 편으로 집단 내·집단 간 특성을 비교한 연구가 5 편

Table 2. Comparison of study types

\begin{tabular}{lllllll}
\hline & \multicolumn{2}{c}{ Domestic } & & \multicolumn{2}{c}{ International } & \multirow{2}{*}{ Total } \\
\cline { 2 - 3 } & CSD & JSLHD & & JSLHR & JFD & \\
\hline Treatment study & $3(100)$ & $2(100)$ & & $2(17)$ & $1(9)$ & $8(29)$ \\
Comparative study & $0(0)$ & $0(0)$ & & $6(50)$ & $6(55)$ & $12(42)$ \\
Characteristic study & $0(0)$ & $0(0)$ & & $4(33)$ & $4(36)$ & $8(29)$ \\
Total & $3(100)$ & $2(100)$ & & $12(100)$ & $11(100)$ & $28(100)$ \\
\hline
\end{tabular}

Values are presented as number of publications (\%).

CSD = Communication \& Sciences Disorders; JSLHD = Journal of Speech-Language \& Hearing Disorders; JSLHR = Journal of Speech, Language, and Hearing Research; $\mathrm{JFD}=$ Journal of Fluency Disorders. 
(63\%)으로 가장 많았으며(예: Ambrose et al., 2015; Kefalianos et al., 2017a, 2017b; Shimada, Toyomura, Fujii, \& Minami, 2018; Watts et al., 2017), 집단간 특성 비교연구는 2편(25\%; 예: Smith et al., 2017; Usler et al., 2017), 말더듬 집단 내 특성은 1편(13\%; 예: Franken, Koenraads, Holtmaat, \& van der Schroeff, 2018)으로 나타났다.

중재 및 비교, 비교연구의 집단특성: 국내외의 중재 및 비교, 비교 연구를 비교집단 특성에 따라 분류한 결과, 국내 연구는 말더듬지 속, 회복집단 간 비교가 4편(80\%)으로 가장 많았으며(예: Lee \& Sim, 2015, 2016, 2017; Park et al., 2015), 말더듬집단의 중재효과를 제시하기 위한 단일대상연구는 1편(20\%; 예: Jung \& Kwon, 2002) 으로 나타났다(Table 5).

국외 연구는 말더듬지속, 회복집단 간 비교가 5편(33\%; 예: Kloth

Table 3. Comparison of participants' age

\begin{tabular}{|c|c|c|c|c|c|}
\hline & \multicolumn{2}{|c|}{ Domestic } & \multicolumn{2}{|c|}{ International } & \multirow{2}{*}{ Total } \\
\hline & CSD & JSLHD & JSLHR & JFD & \\
\hline \multicolumn{6}{|c|}{ Age (yr) } \\
\hline$<1$ & $0(0)$ & $0(0)$ & $3(25)$ & $0(0)$ & $3(11)$ \\
\hline $2-6$ & $3(100)$ & $2(100)$ & $9(75)$ & $11(100)$ & $25(89)$ \\
\hline Total & $3(100)$ & $2(100)$ & $12(100)$ & $11(100)$ & $28(100)$ \\
\hline
\end{tabular}

Values are presented as number of publications $(\%)$.

CSD = Communication \& Sciences Disorders; JSLHD = Journal of Speech-Language \& Hearing Disorders; JSLHR = Journal of Speech, Language, and Hearing Research; $\mathrm{JFD}=$ Journal of Fluency Disorders. et al., 1999; Paden et al., 2002; Ryan, 2001; Throneburg \& Yairi, 2001; Yairi \& Ambrose, 1999), 말더듬집단 내의 비교연구(단일대 상연구 포함)가 5편(33\%; 예: Buhr \& Zebrowski, 2009; Millard et al., 2008; Riley \& Ingham, 2000; Trajkovski et al., 2009; Wagovich et al., 2009), 말더듬집단과 통제집단 간 비교한 연구가 4 편(24\%; 예: Hilger et al., 2016; Kloth et al., 1995, 1998; Sawyer \& Yairi, 2010), 말더듬지속, 회복집단과 통제집단 비교가 1편(6\%; 예: Hall et al., 1999)으로 나타났다.

특성 및 비교연구, 특성연구의 집단특성: 국내외의 특성 및 비교, 특성연구를 비교집단 특성에 따라 분류한 결과, 국내에서는 해당 연구가 없었다. 국외의 경우, 총 9편으로 말더듬지속, 회복집단과 통 제집단 간 비교가 5편(56\%)으로 가장 많았으며(예: Ambrose et al., 2015; Kefalianos et al., 2017b; Smith et al., 2017; Usler et al., 2017), 말더듬집단(단일대상연구 포함) 내의 비교연구가 2 편(22\%; 예: Franken et al., 2018; Shimada et al., 2018), 말더듬지속, 회복집단 간 비교가 1편(11\%; 예: Kefalianos et al., 2017a), 말더듬집단과 통제 집단 간 비교연구가 1편(11\%; 예: Watts et al., 2017)으로 나타났다.

연구 기간 및 주기

국내외 말더듬아동을 대상으로 한 논문의 연구기간을 분석한 결과는 Table 6과 같다.

중재 및 비교, 비교연구: 국내외의 중재 및 비교, 비교연구를 연구

Table 4. Comparison of comparative groups

\begin{tabular}{|c|c|c|c|c|c|c|}
\hline & \multicolumn{3}{|c|}{ Treatment vs. comparative } & \multicolumn{3}{|c|}{ Characteristic vs. comparative } \\
\hline & Domestic & International & Total & Domestic & International & Total \\
\hline Between group & $4(80)$ & $10(66)$ & $14(70)$ & $0(0)$ & $2(25)$ & $2(25)$ \\
\hline Within group & $0(0)$ & $2(13)$ & $2(10)$ & $0(0)$ & $1(13)$ & $1(13)$ \\
\hline Between group \& within group & $0(0)$ & $1(6)$ & 1 (5) & $0(0)$ & $5(63)$ & $5(63)$ \\
\hline Single subject study & $1(20)$ & $2(13)$ & $3(15)$ & $0(0)$ & $0(0)$ & $0(0)$ \\
\hline Total & $5(100)$ & $15(100)$ & $20(100)$ & $0(0)$ & $8(100)$ & $8(100)$ \\
\hline
\end{tabular}

Values are presented as number of publications (\%).

Table 5. Comparison of group characteristics

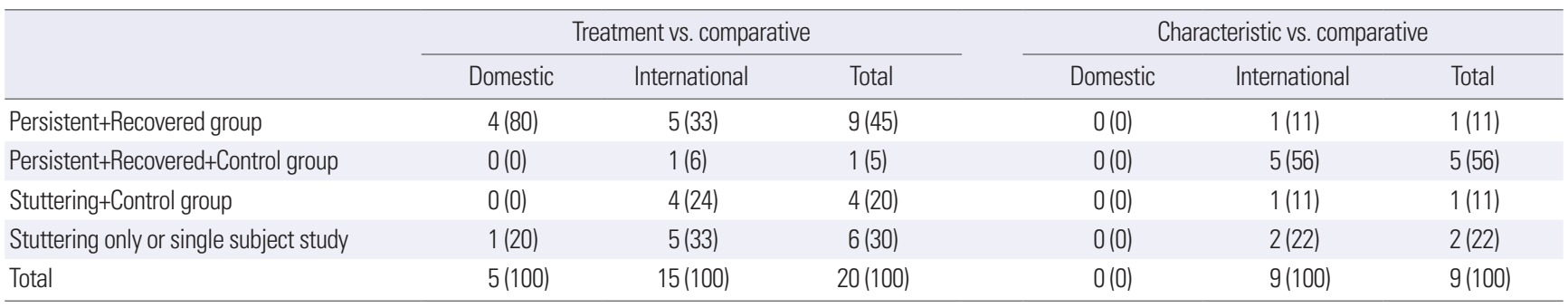

Values are presented as number of publications (\%). 
기간에 따라 분류한 결과, 국내 연구에서는 18 개월 연구가 3 편(60\%) 으로 가장 많았으며(예: Lee \& Sim, 2015, 2017; Park et al., 2015), 6-11개월 연구는 단일대상연구를 포함하여 2편(40\%; 예: Jung \& Kwon, 2002; Lee \& Sim, 2016)으로 나타났다.

국외 연구는 24개월 연구가 4편(26\%; 예: Buhr \& Zebrowski, 2009; Hall et al., 1999; Paden et al., 2002; Ryan, 2001), 6-11개월 연 구가 4편(26\%; 예: Riley \& Ingham, 2000; Sawyer \& Yairi, 2010; Trajkovski et al., 2009; Wagovich et al., 2009), 12개월 연구는 3편 (20\%; 예: Millard et al., 2008; Kloth et al., 1995, 1998), 36개월(예: Throneburg \& Yairi, 2001), 48개월(예: Yairi \& Ambrose, 1999) 연 구는 각각 1 편씩으로 나타났다.

국내연구와 다르게 국외연구 2편(14\%; 예: Hilger et al., 2016; Kloth et al., 1999)은 5년 이상의 연구기간 동안 말더듬아동의 특성 뿐만 아니라 부모의 특성까지 파악하였다.

또한, 국내 종단연구의 기간은 18 개월(예: Lee \& Sim, 2015, 2017) 이었고 6 개월 주기로 데이터를 수집하였고, 국외 종단연구들의 기 간은 24-36개월이었고(예: Hall et al., 1999; Paden et al., 2002; Ryan, 2001; Throneburg \& Yairi, 2001) 1년 주기로 데이터를 수집한 것으 로 나타났다.

특성 및 비교연구: 국내외의 특성 및 비교, 특성연구를 연구기간 에 따라 분류한 결과, 국내에서는 이러한 연구가 진행되지 않았다. 하지만 국외에서는, 5 년 이상의 연구가 5편(55\%; Kefalianos et al., 2017a, 2017b; Franken et al., 2018; Smith et al., 2017; Usler et al., 2017)으로 나타났으며, 12개월(예: Watts et al., 2017), 24개월(예: Ambrose et al., 2015), 36개월(예: Shimada et al., 2018) 연구, 48개월 (예: Ambrose et al., 2015) 연구도 각각 1편씩으로 총 9편의 국외 논 문이 파악되었다. 특히 Ambrose 등(2015)의 연구는 비정상적 비유

Table 6. Comparison of study period

\begin{tabular}{|c|c|c|c|c|c|c|}
\hline & \multicolumn{3}{|c|}{ Treatment vs. comparative } & \multicolumn{3}{|c|}{ Characteristic vs. comparative } \\
\hline & $\begin{array}{c}\text { Domes- } \\
\text { tic }\end{array}$ & $\begin{array}{c}\text { Interna- } \\
\text { tional }\end{array}$ & Total & $\begin{array}{l}\text { Domes- } \\
\text { tic }\end{array}$ & $\begin{array}{c}\text { Interna- } \\
\text { tional }\end{array}$ & Total \\
\hline \multicolumn{7}{|c|}{ Study period (mo) } \\
\hline $6-11$ & $2(40)$ & $4(26)$ & $6(30)$ & $0(0)$ & $0(0)$ & $0(0)$ \\
\hline 12 & $0(0)$ & $3(20)$ & $3(15)$ & $0(0)$ & $1(11)$ & $1(11)$ \\
\hline 18 & $3(60)$ & $0(0)$ & $3(15)$ & $0(0)$ & $0(0)$ & $0(0)$ \\
\hline 24 & $0(0)$ & $4(26)$ & $4(20)$ & $0(0)$ & $1(11)$ & $1(11)$ \\
\hline 36 & $0(0)$ & $1(6)$ & $1(5)$ & $0(0)$ & $1(11)$ & $1(11)$ \\
\hline 48 & $0(0)$ & $1(6)$ & $1(5)$ & $0(0)$ & $1(11)$ & $1(11)$ \\
\hline$>60$ & $0(0)$ & $2(12)$ & $2(10)$ & $0(0)$ & $5(55)$ & $5(55)$ \\
\hline Total & $5(100)$ & $15(100)$ & $20(100)$ & $0(0)$ & $9(100)$ & $9(100)$ \\
\hline
\end{tabular}

Values are presented as number of publications (\%).
창성 빈도를 48 개월 동안 측정하였고, 다른 변인들을 24 개월 동안 추적하여 개별 논문으로 분석하였다.

국외의 특성 및 비교연구 6편은 cohort 집단연구로 2편(예: Shimada et al., 2018; Watts et al., 2017)을 제외한 4편(예: Kefalianos et al., 2017a, 2017b; Smith et al., 2017; Usler et al., 2017)의 논문은 5년 이상 연구를 수행하여 말더듬지속아동과 말더듬회복아동의 특성 을 비교하였다.

연구대상자수

국내외 말더듬아동을 대상으로 한 논문의 연구대상자 수는 Table 7과 같다.

중재 및 비교, 비교연구: 국내외의 중재 및 비교, 비교연구를 연구 대상자 수에 따라 분류한 결과, 국내연구에서는 11-20명이 3편 (75\%)으로 가장 많았으며(예: Lee \& Sim, 2015, 2017; Park et al., 2015), 10 명 미만 연구는 단일대상연구 1편(25\%; 예: Jung \& Kwon, 2002)으로 나타났다.

국외 연구에서는 21-50명 연구가 4편(26\%; 예: Hall et al., 1999; Kloth et al., 1999; Ryan, 2001; Sawyer \& Yairi, 2010)으로 가장 많았 으며, 1-10명 연구 3편(20\%; 예: Millard et al., 2008; Trajkovski et al., 2009; Wagovich et al., 2009), 11-20명 연구 3편(20\%; 예: Buhr \& Zebrowski, 2009; Riley \& Ingham, 2000; Throneburg \& Yairi, 2001), 81-100명 연구도 3편(20\%; 예: Kloth et al., 1995; Paden et al., 2002; Yairi \& Ambrose, 1999)으로 나타났다. 그 밖에 52명 연구 1편(예: Kloth et al., 1998), 115명 연구 1편(예: Hilger et al., 2016) 등으로 분 석되었다.

특성 및 비교연구: 국내외의 특성 및 비교, 특성연구를 연구대상 자 수에 따라 분류한 결과, 국내의 경우는 해당 연구가 없었다. 국외

Table 7. Comparison of number of participants

\begin{tabular}{cccccccc}
\hline & \multicolumn{3}{c}{ Treatment vs. comparative } & & \multicolumn{3}{c}{ Characteristic vs. comparative } \\
\cline { 2 - 3 } & Domestic & $\begin{array}{c}\text { Interna- } \\
\text { tional }\end{array}$ & Total & & $\begin{array}{c}\text { Domes- } \\
\text { tic }\end{array}$ & $\begin{array}{c}\text { Interna- } \\
\text { tional }\end{array}$ & Total \\
\hline Number of participants & & & & & & \\
$1-10$ & $1(25)$ & $3(20)$ & $4(21)$ & & $0(0)$ & $0(0)$ & $0(0)$ \\
$11-20$ & $3(75)$ & $3(20)$ & $6(32)$ & & $0(0)$ & $1(11)$ & $1(11)$ \\
$21-50$ & $0(0)$ & $4(26)$ & $4(21)$ & & $0(0)$ & $1(11)$ & $1(11)$ \\
$51-80$ & $0(0)$ & $1(6)$ & $1(5)$ & & $0(0)$ & $1(11)$ & $1(11)$ \\
$81-100$ & $0(0)$ & $3(20)$ & $3(16)$ & & $0(0)$ & $2(22)$ & $2(22)$ \\
$\geq 101$ & $0(0)$ & $1(6)$ & $1(5)$ & & $0(0)$ & $4(44)$ & $4(44)$ \\
Total & $4(100)$ & $15(100)$ & $19(100)$ & & $0(0)$ & $9(100)$ & $9(100)$ \\
\hline
\end{tabular}

Values are presented as number of publications (\%). 
Table 8. Comparison of dependent variables

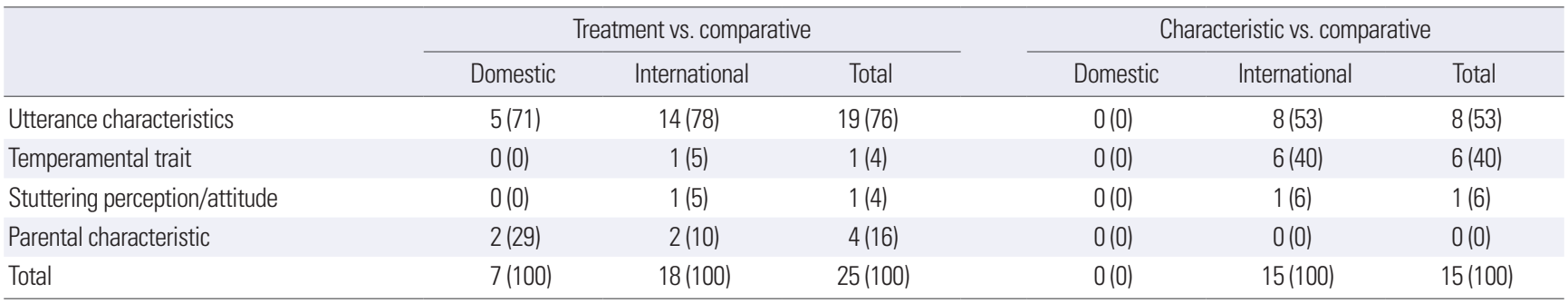

Values are presented as number of publications (\%).

논문에서는 101명 이상 연구가 4편(44\%; 예: Kefalianos et al., 2017a, 2017b; Smith et al., 2017; Watts et al., 2017)으로 가장 많았으며, 81100 명 연구가 2편(22\%; 예: Ambrose et al., 2015)으로 나타났다. 11-20 명 연구 1편(예: Franken et al., 2018), 21-50명 연구 1편(예: Shimada et al., 2018), 67명 연구 1편(예: Usler et al., 2017)으로 나타났다.

국외의 총 9편 중, 6편이 cohort 집단연구로 2편(예: Shimada et al., 2018; Usler et al., 2017)을 제외한 4편(예: Kefalianos et al., 2017a, 2017b; Smith et al., 2017; Watts et al., 2017)의 논문은 100명이 넘는 말더듬지속아동과 말더듬회복아동의 특성을 비교하였다.

\section{종속변인 분석결과}

2 개 이상의 종속변인 항목에 해당될 경우, 각각의 항목에 독립된 논문으로 분석하였다(Table 8, Appendix 1).

중재 및 비교, 비교연구: 국내 연구의 경우, 중재 전후의 발화특성 의 변화를 측정하기 위해서 발화분석을 통한 말더듬 유형 및 빈도, 말더듬 음절비율(\%SS), 문장길이에 따른 비유창성 유형, 그리고 부 모의 의사소통행동, 반응시간, 조음속도 등을 분석하였다. 국외 연 구의 경우 발화특성의 변화에 관한 연구들은 국내와 비슷한 종속 변인들을 분석하였고, 그 외에 아동의 조음속도, 음향학적 분석, 운동능력, 언어능력, 말더듬특성, 말의 자연스러움 등을 분석하였 다. 이외에 부모의 행동적 특성과 말 특성 등의 관계를 통해 중재효 과를 객관적으로 분석하였다.

국내외 문헌 모두에서 아동의 발화를 통해 말더듬 유형별 특성, 중증도와 말더듬 비율, 말속도 등의 변화를 연구한 논문들이 총 25 편 중 19편(76\%)으로 가장 많은 비중을 차지하였다(예: Kloth et al., 1995; Lee \& Sim, 2015, 2017; Paden et al., 2002; Park et al., 2015; Sawyer \& Yairi, 2010; Yairi \& Ambrose, 1999).

특성 및 비교연구: 국내외 특성 및 비교, 특성연구들을 종속변인 에 따라 분류한 결과, 국내의 경우는 해당 연구가 없었다. 국외 연구 에서는 발화특성(말더듬 특성, 비유창성 정도나 말더듬 중증도, 언 어능력, 조음운동능력 등)과 관련된 연구가 $53 \%$ 로 가장 높게 나타
났다(예: Franken et al., 2018; Kefalianos et al., 2017a, 2017b; Shimada et al., 2018; Usler et al., 2017; Watts et al., 2017). 기질적 특성 에서는 아동과 어머니의 기질, 불안, 행동문제에 관한 연구가 이루 어졌다(예: Ambrose et al., 2015; Franken et al., 2018; Kefalianos et al., 2017a, 2017b; Smith et al., 2017). 기질적 혹은 말더듬에 관한 인 식 변화는 STAIC 심리검사도구나 말더듬 관련 검사를(예: Short Temperament Scale for Children, Strengths and Difficulties Questionnaire) 사용하여 객관적인 측정을 실시하였다(Kefalianos et al., 2017a, 2017b).

\section{독립변인 분석 결과}

국내연구의 중재 및 비교, 비교연구의 경우, 발달성말더듬아동 대상의 연구로 말더듬 치료는 부모가 치료에 함께 참여하는 Palin 부모-아동상호작용치료(예: Lee \& Sim, 2016; Park et al., 2015), 직 접치료(예: Lee \& Sim, 2015, 2017)를 적용한 연구들이 대부분이었 고, 연장기법의 중재와 발화수집을 적용한 연구(예: Jung \& Kwon, 2002)가 포함되었다.

국외연구에서는 Palin 부모-아동상호작용치료를 사용하는 연 구(Millard et al., 2008)와 말운동 훈련 및 연장발화 기법을 사용한 연구(Riley \& Ingham, 2000), 음절단위치료(syllable-timed speech) 를 사용한 연구(Trajkovski et al., 2009)가 포함되었다(Appendix 1).

\section{논의 및 결론}

본 연구는 지난 30 년 동안 실시된 말더듬 종단연구의 동향을 살 펴보기 위해 최근 30 여 년간 말더듬아동의 종단연구 논문들의 연 구형태, 연구대상, 실험절차, 그리고 종속변인과 독립변인을 미시적 인 차원에서 수량화하여 분석하였다. 이러한 본 연구의 미시적 수 치비교는 종단연구와 SDUA 앱개발의 방향을 모색하는 데 기초자 료로 사용할수 있을 것이다.

거시적 차원에서 본 연구에 포함된 선행연구들을 살펴보면 말더 
듬집단과 통제집단 간의 비교보다는 말더듬지속집단과 회복집단 간 비교를 대규모 인원을 피험자로 확보하여 실시된 미국과 호주의 대규모 연구가 연구의 주류를 형성하고 있다고 파악된다.

첫 번째, 초기 말더듬아동을 대상으로 한 체계적인 종단연구는 Illinois 대학의 Yairi 교수에 의해 1977년부터 미국 Illinois 대학에 서 시작된 Illinois Stuttering Research Program을 통해 발전되었으 며, 이 프로그램에 의해 실시된 대규모 초기 말더듬아동을 대상으 로 한 종단연구는 1999년에 본격적으로 발표되기 시작하였다. 이 프로그램에서 실시된 종단연구는 단순히 일반집단과 초기 말더듬 집단의 비교보다는 말더듬회복집단과 지속집단의 비교에 더 많은 시간을 투자하였다. Hall 등(1999)의 연구는 2년 동안 말더듬지속 집단, 회복집단 그리고 통제집단별로 각각 8 명을 대상으로 하여 총 24 명의 발화를 분석하여 조음속도를 집단 간 비교하였다. Yairi와 Ambrose (1999)의 연구에서는 Hall 등(1999)의 연구를 확장하여, 4 년 동안 6개월 주기로 자료를 수집하였으며, 연구대상자 수도 말 더듬지속집단 22 명, 말더듬회복집단 22 명으로 장기간의 대규모 종 단연구를 수행하였다. 이 종단연구에서는 SLD 빈도, 반복단위, 부 모에 의한 말더듬 정도 평가 및 언어능력을 분석하였으나, 후속연 구인 Throneburg와 Yairi (2001) 및 Paden 등(2002)의 연구에서는 말더듬지속아동과 회복아동을 대상으로 말더듬 빈도뿐만 아니라 말더듬 유형, 지속시간 및 음운능력을 분석함으로써 관심의 변인 을 확장시켰다. 최근 Ambrose 등(2015)의 연구에서는 두 집단 간 그리고 집단 내 비교를 통해 말더듬 특성, 조음능력 및 언어능력 이 외에 아동행동목록표(Children's Behavior Questionnaire, $\mathrm{CBQ}$ ) 를 사용하여 아동의 기질도 분석함으로써, 종단연구의 관심범위가 말더듬 특성 이외에 기질적인 요인까지 확대되었다. 말더듬아동의 기질적 특성에 관한 연구가 최근에 들어 활발하게 진행되는 것을 고려해 볼 때, 말더듬회복집단과 지속집단을 대상으로 실시된 종 단연구의 이러한 발전 추세는 말더듬아동의 특성에 관한 연구의 발전과정에 영향을 받은 것으로 볼 수 있다. 두 번째, 미국에서 또 다른 학령전기 아동을 대상으로 대규모 종단연구는 Purdue대학 의 Smith 교수에 의해 진행되는 The Purdue Stuttering Project이 다. Smith 등(2017)의 연구는 말더듬지속집단 20명, 말더듬회복집 단 121 명, 통제집단 702 명을 대상으로 한 대규모 연구로 아동의 기 질 및 불안을 집단 간 비교하였다. 아울러 Usler 등(2017)의 연구에 서는 말더듬지속집단 21 명과 말더듬회복집단 15 명 그리고 통제집 단 31명을 대상으로 하여 조음운동능력을 집단 간 비교하였다. 마 지막으로는, 호주에서 실시된 Kefalianos 등(2017b)의 연구로 대규 모 연구 프로젝트인 Early Language in Victoria Study에 포함된 말 더듬지속집단 36 명, 말더듬회복집단 67 명 총 103 명을 대상으로 언
어능력 및 아동의 기질과 행동문제를 집단 간 비교하였다.

위에서 언급한 것 바와 같이 학령전기 말더듬아동의 종단연구 는 말더듬의 지속 및 회복요인을 찾아내기 위해 대규모 피험자를 확보하여 말더듬지속집단과 회복집단을 비교하거나 통제집단을 포함하여 집단 간 비교를 실시하였다. 이와 같은 대규모 연구가 시 사하는 바는 향후 종단연구가 체계적으로 진행되기 위해서는 연구 비 지원을 통한 지속적인 연구가 이루어져야 하며, 더불어 말더듬 회복과 지속요인을 파악하기 위해 독립변수와 종속변수의 범위가 확장되어야 하며 아울러 장기적인 데이터 수집을 위한 자동화시스 템 구축을 위해서는 IT와 융합된 접근법이 요구된다고 볼 수 있다.

따라서 기존의 선행연구를 통한 연구형태, 연구대상, 실험절차 등을 분석한 연구결과는 제한적이라고 판단되어, 향후 종단연구의 방향을 설정하기 위해서 종속변수와 독립변수에 관한 연구결과를 중심으로 논의를 진행하고자 한다.

선정된 연구들의 종속변인을 분석한 결과, 국내외 연구 모두, 대 부분 아동의 발화특성 관련한 연구였으며 부모특성, 기질적 특성 등의 국외 연구가 있었다. 발화특성의 경우, 국내 연구는 말더듬 유 형과 빈도, 아동 및 부모의 조음속도에 초점을 맞춘 경향을 보였으 며, 국외 연구는 이외에도 언어능력, 조음속도, 음향학적 분석, 운 동능력, 말의 자연스러움을 분석하였고 기질적 특성과 말더듬 인 식 등의 변화는 아동 기질척도, OASES (Overall Assessment of the Speaker's Experience of Stuttering)와 같은 검사도구를 활용하여 측정하였다.

첫 번째, 말더듬 특성으로 말더듬회복집단은 말더듬 초기에 비 유창성 빈도와 중증도가 최고에 달하였다가 1 년 이내에 완화되는 경향을 보인 반면 말더듬 발생 후 1 년 동안 말더듬 수준이 일정하게 유지된다면 말더듬이 지속되는 지표로 볼 수 있다고 설명하였다 (Yairi \& Ambrose, 1999). 말더듬지속집단은 3년 동안 비유창성의 빈도와 유형, 지속시간이 유지가 되었지만 증가하지는 않았다. 반 면, 말더듬회복집단은 비유창성 빈도가 연구 초반 현저히 줄어들 어(Throneburg \& Yairi, 2001) 집단 간에 말더듬 초기와 3년 동안 다른 양상을 보인 것으로 나타났다.

문장 내에서 말더듬 위치는 문장 시작부분에서 주로 나타났고, 비정상적, 정상적 비유창성은 복잡하고 긴 문장에서 더 많이 나타 났다(Buhr \& Zebrowski, 2009). 수정 유형을 포함한 문장 비율은 증가하였고 긴 문장에서 간투사와 말더듬은 더 나타났다(Wagovich et al., 2009). 말더듬지속집단은 발화길이, 비유창한 발화길이 도 계속 증가하면서 비정상적 비유창성 빈도 역시 증가하였다(Lee \& Sim, 2015). 말더듬집단은 일반아동집단에 비해 문장 내 비유창 성군(cluster)의 수가 많았고, 그 길이도 길었으며, 시간이 경과함에 
따라 비유창성군(cluster)의 수와 길이는 말더듬 회복집단과 지속 집단에서 모두 감소하는 경향을 보였으나, 연구 6개월 시점에 말더 듬회복집단은 지속집단에 비해 비유창성군(cluster) 내 비유창성 의 비율이 유의하게 적게 나타났다(Sawyer \& Yairi, 2010).

두 번째, 언어적 특성으로 말더듬회복집단과 말더듬지속집단 간 에 공식언어검사 점수에서 차이가 없었고(Ryan, 2001), 말더듬집단 과 일반아동집단 간에도 언어능력에서 차이가 없고 정상규준에 따른 발달을 하는 것으로 나타났다(Watts et al., 2017). 그러나 최근 연구들에서는 말더듬지속집단은 말더듬회복집단과 일반집단에 비해 공식언어검사에서 낮은 수행도를 보였고(Ambrose et al., 2015) 말더듬회복집단이 말더듬지속집단에 비해 7세 시점에 더 높은 언 어적 기술을 보이는 것으로 나타났다(Kefalianos et al., 2017a). 또 한, 1 세 6 개월 시점에 보이는 아동의 언어적 능력이 말더듬의 자연 회복 또는 지속으로 이끄는 잠재적인 요인인 것으로 나타났다(Shimada et al., 2018). 선행연구 결과, 집단 간 언어능력은 연구마다 상 이한 결과를 보였다.

세 번째, 조음음운적 특성으로 말더듬지속집단의 경우, 말더듬 회복집단에 비해 음운발달이 지속적으로 이루어지지는 않았고, 음운발달 지체가 나타났으나, 말더듬 발생 1년 후 평가를 실시하였 을 때, 말더듬지속집단은 말더듬회복집단 수준에 도달하여 말더듬 회복집단과 말더듬지속집단 간의 음운오류 점수에서 유의미한 차 이가 나타나지 않았고, 말더듬 발생 2년 후 평가 시에는, 말더듬지 속집단의 발달 속도가 말더듬회복집단보다 더 빠르게 나타나 두 집단 간 음운오류 점수의 차이가 같게 나타났다(Paden et al., 2002). 그러나 다른 연구에서는 말더듬지속집단은 말더듬회복집단보다 조음속도의 변이성과 빠른 말속도를 보였고(Kloth et al., 1995, 1999; Hall et al., 1999), 말더듬지속집단은 말더듬회복집단과 일반집단 에 비해 조음정확도에서 낮은 수행도, 조음기관 운동성에서 변이 성을 보였다(Ambrose et al., 2015). 조음속도를 초당 음절수로 측 정 시, 말더듬회복집단과 말더듬지속집단, 일반아동집단 간 차이 는 없었고, 초당 음소로 조음속도를 측정했을 때, 일반아동집단과 말더듬회복 및 말더듬지속집단 간 차이가 나타났다(Hall et al., 1999). 선행연구 결과, 집단 간 조음음운능력에서도 연구마다 상이 한 결과를 보고하였다.

네 번째, 기질적 특성으로 말더듬회복집단 및 말더듬지속집단 그리고 일반아동집단 간 불안, 정서 및 행동기능, 기질측면의 차이 가 나타나지 않았다(Smith et al., 2017). 3-4세 말더듬아동을 말더 듬중증도로 분류하였을 때, 기질에 따른 집단 간 차이는 나타나지 않았고, 말더듬행동으로 분류된 집단의 경우, 기질에 따른 차이가 $5 \%$ 수준에서 단 6 명만이 유의한 차이를 보이는 것으로 나타났다
(Kefalianos et al., 2017b). 또한, 말더듬회복집단이 말더듬지속집단 에 비해 7세 시점에 비구어적 인지, 기질, 부모보고에 의한 삶의 질 에서도 차이가 나타나지 않았다(Kefalianos et al., 2017a). 선행연구 결과, 집단 간 기질적 특성에서는 연구 간에 차이가 없는 것으로 나 타났다.

다섯 번째, 운동협응적 특성으로 말더듬아동집단과 일반아동 집단은 양손을 사용한 운동 타이밍 능력에 차이가 없어서, 이러한 능력이 말더듬 지속과 회복에 관련 있는 잠재적인 요인으로 볼 수 없다고 하였으나(Hilger et al., 2016) 또 다른 연구는 말더듬지속집 단이 말더듬회복집단에 비해 말의 정교함이 떨어지고, 말·운동 협 응능력이 부족하다고(Usler et al., 2017)하였다. 선행연구 결과, 집 단 간 운동협응력에서도 연구마다상이한 결과를 보고하였다.

여섯 번째, 부모특성으로, 부모의 조음속도, 의사소통 스타일과 문장복잡성이 말더듬회복집단과 말더듬지속집단을 판별하는 예 측기준이라고 주장하였다(Kloth et al., 1995, 1999). 그러나 말더듬 지속집단과 말더듬회복집단 어머니의 발화는 평가 후 3,18 개월 시 점에서 집단 간, 시점 간 차이는 나타나지 않아서 집단을 변별하는 요인이 아닌 것으로 나타났다(Park et al., 2015). 선행연구 결과, 집 단간 부모특성에서도 연구마다 상이한 결과를 보고하였다.

선행연구 결과들을 통해 말더듬 회복 예측요인을 종합하여 살펴 보면, (1) 비유창성 특성, (2) 조음속도, (3) 부모특성 등이 중요한 요 인임을 알 수 있었다(Hall et al., 1999; Kloth et al., 1995, 1999; Throneburg \& Yairi, 2001; Yairi \& Ambrose, 1999). 그 밖에 아동의 언어능 력, 조음음운능력, 기질적 특성, 운동협응력 등의 요인은 연구 간에 상반된 결과를 보여서 회복 예측요인이라고 단언할 수는 없는 것으 로 나타났다.

독립변인을 분석한 결과, 국내외 중재 및 비교연구와 특성 및 비 교연구 모두, 행동변화를 살펴보려는 연구가 대부분이었으며, 중재 연구 8편 중 5편의 치료접근법은 주로 Palin 부모-아동 상호작용치 료를 적용한 것으로 나타났다. 그 밖에 말운동 훈련 및 발화연장 등 의 프로그램(Riley \& Ingham, 2000; Trajkovski et al., 2009)으로도 치료 효과를 검증하였으나 직접적인 치료법보다는 간접적인 치료 법을 채택한 초기 말더듬아동을 대상으로 한 종단연구의 특성으 로 판단된다. 말더듬아동 치료 프로그램이 더 다양하지만 본 연구 의 기준에 따라 선정된 논문들은 Palin 부모-아동 상호작용치료 프 로그램을 주로 적용하여 해석의 주의를 요하며 다양한 치료기법을 적용한 종단연구가 필요하다. Palin 부모-아동 상호작용치료(Lee \& Sim, 2015, 2016, 2017; Millard et al., 2008)와 Syllabled-time speech 치료기법(Trajkovski et al., 2009), 연장기법(Jung \& Kwon, 2002)이 취학전 말더듬아동의 말더듬 감소에 효과적이었다. Speech motor 
training (SMT) 치료기법은 보통 정도의 수준이나 유의한 말더듬 감소를 보였으며. 연장기법은 SMT 치료기법에 비해 말더듬 감소폭 이 더 컸다(Riley \& Ingham, 2001).

본 연구를 통해 밝혀진 연구결과들을 토대로 향후 한국 말더듬 아동의 종단연구에 대한 연구방향과 필요성을 제시하면 다음과 같다.

첫째, 학령전기 대규모 말더듬아동의 특성연구를 통해 한국 말 더듬아동의 비유창성을 포함한 말.언어 특성에 대한 이해를 높이 는 것이 필요하다. 국외에서는 국가 차원에서 100 명 이상을 대상으 로 장기간에 걸쳐 특성연구가 진행되고 있으며, 이러한 대규모 종단 적 연구를 통해 기존의 선행연구의 결과들과 상이한 특성들이 밝 혀지고 있다. 하지만 국내에서는 종단적으로 이루어진 특성연구가 부재한 실정이다. Kefalianos 등(2017a)은 cohort 집단연구를 통해 호주 7세 아동들의 생후부터 7년간 말더듬아동의 특성을 분석한 결과, 말더듬 회복률은 $65 \%$ 에 달했고, 언어능력은 말더듬회복에 강한 요소였으나 비구어적 인지, 기질, 부모가 보고한 삶의 질은 영 향력이 없다고 보고하였다. 한국어의 언어적 차이와 문화적 차이 가 어떻게 말더듬의 발달과정에 영향을 미치는가를 파악하기 위해 서는 한국에서도 이와 같은 대규모의 말더듬아동을 대상으로 장 기간의 특성연구가 요구된다.

둘째, 말더듬아동을 대상으로 한 다양한 치료법들이 적용되고 가족기반의 중재효과에 대한 장기간의 연구가 진행되는 것이 필요 하다. 국내 연구는 모두 중재연구로 수행되었으나 국외에 비해 연구 편수가 상대적으로 부족한 상황이고 다양한 치료프로그램이 적용 되지 못하였다. 문헌 분석결과, 대부분 Palin 부모-아동 상호작용치 료법을 채용하였으며, 말운동 훈련 및 발화의 연장 등의 프로그램만 으로 치료 효과를 검증하려고 하였기에, 다양한 치료프로그램의 효 과 검증은 이루어지지 않고 있었다. 주로 아동의 발화분석 연구가 대부분이었으나 취학전 말더듬아동의 회복에서 가족의 영향을 배 제할 수 없으므로, 말더듬아동과 가족을 함께 대상으로 하는 치료 를 통해치료 효과를 검증하는 것이 필요하다(Millard et al., 2008).

셋째, 종단연구를 진행함에 있어 더 많은 대상자와 통제집단 비 교 등의 증거기반 치료의 기준에 충실한 연구가 필요하다. Bloodstein과 Bernstein Ratner (2008)가 제안한 증거중심 치료 기준을 가지고 논문들을 분석한 결과, 국내외 중재논문 대다수가 변인들 을 객관적인 척도로 측정하는 것으로 나타났다. 선정된 논문들은 모두 종단연구로 국내 연구는 18 개월 이상, 국외 연구는 24 개월 이 상의 연구가 많았으며, 2 가지 이상의 종속변인을 6 개월 또는 12 개 월 주기로 최소 2 회 이상 측정하였고, 국외 연구의 경우 5 년 이상의 장기간 연구도 많은 것으로 나타났다. 또한, 단일대상연구 3 편을 포
함한 4편(Jung \& Kwon, 2002; Millard et al., 2008; Trajkovski et al., 2009; Wagovich et al., 2009) 이외의 국외 논문들은 10 명 이상의 말 더듬집단을 대상으로 집단 간 비교를 실시하여, 증거중심 치료의 연구절차의 기준에 모두 부합하는 것으로 분석되었다. 이러한 결 과는 언어병리학에서 강조되고 있는 증거중심 치료(Bernstein Ratner, 2005; Bothe, 2004)의 요건을 갖춘 말더듬아동 대상의 종단연 구가 국외뿐만 아니라 국내 연구에서도 진행되고 있다는 것을 보여 준다. 이는 Shin 등(2009)의 연구에 포함된 2008년까지 수행된 국 내 유창성장애 연구들에서 주로 사용된 단일대상연구들이 과학적 인 근거를 제시하지 못하였던 제한점을 보완하려는 노력이 진행 중 임을 시사한다. 그러나 최근의 국내 논문은 말더듬회복집단과 말 더듬지속집단 간의 비교를 수행하였지만 일반아동집단 비교와 집 단별로 10 명 이상의 대상자를 확보하는 보완책이 필요하다.

본 문헌연구를 통해, 말더듬아동 진단 및 치료에 활용하고자 한 국연구재단의 연구지원을 받아 개발 중인 자동발화분석 앱(SDUA) 의 구성요소 및 필요성을 확인하고자 하였다. 문헌연구 결과를 토 대로 SDUA 앱의 구성은 아동의 말더듬 및 언어·말 발달특성, 그리 고 부모특성들의 변화를 측정할 수 있어야 하며, 최소 10 명 이상의 말더듬집단과 일반아동집단별로 2 년 이상의 다년간 데이터 수집 및 분석을 위한 필요성을 확인하였다.

연구의 의의는 (1) 학문적인 측면에서 보면, SDUA 앱을 사용하 여 한국적 종단연구를 통해 초기 말더듬아동의 대규모 데이터를 구축함으로써 외국 기준자료와의 차이점과 공통점을 밝힐 수 있으 며, 한국어권 말더듬아동의 비유창성, 언어발달 및 말속도의 종단 적 특성 파악에 기여할 수 있다. 또한, 일반아동의 특성과 비교하여 초기 말더듬 아동의 차이점과 공통점을 밝힐 수 있다. 말더듬아동 부모의 문장길이, 말속도, 반응시간의 변화를 종단적으로 파악하 여 말더듬의 회복에 미치는 환경요인으로서 부모의 영향을 파악할 수 있다. (2) 임상적인 측면에서 보면, 말더듬으로 진단된 이후 말더 듬의 지속여부를 예측할 수 있는 요인들을 제시하여 조기중재 여 부와 중재 방향 결정에 기여할 수 있다. 초기 말더듬아동을 치료하 는 동안 치료사가 치료시점별로 살펴보아야 할 요인들을 제시하여 객관적인 데이터 기반의 치료를 유도할 수 있다. 한편으로는 부모 가 SDUA를 사용하여 아동의 발화자료를 자발적으로 수집할 수 있 고 아동의 말에 대한 분석이 가능하기 때문에 치료사의 즉각적인 피드백을 받을 수 있으며, 향후 원격치료에도 활용될 수 있다. 또한, 빅데이터 분석에 의해서 말더듬아동의 유창성을 실시간으로 자동 분석하여, 임상학적인 타당성 검증에 기여할 수 있다. 


\section{REFERENCES}

Ambrose, N. G., Yairi, E., Loucks, T. M., Seery, C. H., \& Throneburg, R. (2015). Relation of motor, linguistic and temperament factors in epidemiologic subtypes of persistent and recovered stuttering: initial findings. Journal of Fluency Disorders, 45, 12-26.

Bernstein Ratner, N. (2005). Evidence-based practice in stuttering: some questions to consider. Journal of Fluency Disorders, 30(3), 163-188.

Bloodstein, O., \& Bernstein Ratner, N. (2008). A handbook on stuttering (6th ed.). Clifton Park, NY: Thomson/Delmar Learning.

Bothe, A. K. (2004). Evidence-based treatment of stuttering: empirical bases and clinical applications. Mahwah, NJ: Lawrence Erlbaum Associates.

Buhr, A., \& Zebrowski, P. (2009). Sentence position and syntactic complexity of stuttering in early childhood: A longitudinal study. Journal of Fluency Disorders, 34, 155-172.

Chon, H. J., \& Ambrose, N. (2016). A preliminary study of the non-word repetition abilities of children with persistent and recovered stuttering. Journal of Speech-Language \& Hearing Disorders, 25(4), 211-222.

Erdemir, A., Walden, T. A., Jefferson, C. M., Choi, D., \& Jones, R. M. (2018). The effect of emotion on articulation rate in persistence and recovery of childhood stuttering. Journal of Fluency Disorders, 56, 1-17.

Franken, M. C. J., Koenraads, S. P., Holtmaat, C. E., \& van der Schroeff, M. P. (2018). Recovery from stuttering in preschool-age children: 9 year outcomes in a clinical population. Journal of Fluency Disorders, 58, 35-46.

Hall, K. D., Amir, O., \& Yairi, E. (1999). A longitudinal investigation of speaking rate in preschool children who stutter. Journal of Speech, Language, and Hearing Research, 42(6), 1367-1377.

Hilger, A. I., Zelaznik, H., \& Smith, A. (2016). Evidence that bimanual motor timing performance is not a significant factor in developmental stuttering. Journal of Speech, Language, and Hearing Research, 59(4), 674-685.

Jung, H., \& Kwon, D. H. (2002). The effects of the stuttering therapy program using prolonged speech on the dysfluency improvement of 4-6 years stuttering children. Journal of Speech \& Hearing Disorders, 11(1), 255-278.

Kefalianos, E., Onslow, M., Packman, A., Vogel, A., Pezic, A., Mensah, F., ... \& Reilly, S. (2017a). The history of stuttering by 7 years of age: follow-up of a prospective community cohort. Journal of Speech, Language, and Hearing Research, 60(10), 2828-2839.

Kefalianos, E., Onslow, M., Ukoumunne, O. C., Block, S., \& Reilly, S. (2017b). Temperament and early stuttering development: cross-sectional findings from a community cohort. Journal of Speech, Language, and Hearing Re- search, 60(4), 772-784.

Kloth, S., Janssen, P., Kraaimaat, F., \& Brutten, G. J. (1998). Child and mother variables in the development of stuttering among high-risk children: a longitudinal study. Journal of Fluency Disorders, 23(4), 217-230.

Kloth, S. A., Kraaimaat, F. W., Janssen, P., \& Brutten, G. J. (1999). Persistence and remission of incipient stuttering among high-risk children. Journal of Fluency Disorders, 24(4), 253-265.

Kloth, S. A. M., Janssen, P., Kraaimaat, F. W., \& Brutten, G. J. (1995). Speechmotor and linguistic skills of young stutterers prior to onset. Journal of Fluency Disorders, 20(2), 157-170.

Lee, H., Lee, S., Sim, H., \& Oh, I. (2016). A qualitative study of exploring bullying experiences of adolescents who stutter. The Elementary School Journal, 64(2), 417-450.

Lee, S. B., \& Sim, H. S. (2015). A longitudinal study of utterance length in morphemes as a predictor of treatment outcome in early childhood stuttering. Communication Sciences \& Disorders, 20(2), 189-201.

Lee, S. B., \& Sim, H. S. (2016). Fluency predictor variables in early stuttering intervention for children. Communication Sciences \& Disorders, 21(2), 382396.

Lee, S. B., \& Sim, H. S. (2017). Longitudinal analysis of stuttering like disfluencies as a treatment outcome in early childhood stuttering. Communication Sciences \& Disorders, 22(3), 540-549.

Millard, S. K., Nicholas, A., \& Cook, F. M. (2008). Is parent-child interaction therapy effective in reducing stuttering? Journal of Speech, Language, and Hearing Research, 51(3), 636-650.

O’Brian, S., Jones, M., Packman, A., Menzies, R., \& Onslow, M. (2011). Stuttering severity and educational attainment. Journal of Fluency Disorders, $36(2), 86-92$

Paden, E. P., Ambrose, N. G., \& Yairi, E. (2002). Phonological progress during the first 2 years of stuttering. Journal of Speech, Language, and Hearing Research, 45(2), 256-267.

Park, H. Y., Lee, S. B., \& Sim, H. S. (2015). Communication behaviors of stuttering recovery and stuttering persistent groups. Journal of Speech-Language \& Hearing Disorders, 24(4), 237-248.

Riley, G. D., \& Ingham, J. C. (2000). Acoustic duration changes associated with two types of treatment for children who stutter. Journal of Speech, Language, and Hearing Research, 43(4), 965-978.

Ryan, B. P. (2001). A longitudinal study of articulation, language, rate, and fluency of 22 preschool children who stutter. Journal of Fluency Disorders, 26(2), 107-127. 
Sawyer, J., \& Yairi, E. (2010). Characteristics of disfluency clusters over time in preschool children who stutter. Journal of Speech, Language, and Hearing Research, 53(3), 1191-1205.

Shimada, M., Toyomura, A., Fujii, T., \& Minami, T. (2018). Children who stutter at 3 years of age: a community-based study. Journal of Fluency Disorders, 56, 45-54.

Shin, M., Chon, H., \& Lee, S. (2009). A review of recent trends in stuttering treatment research. Korean Journal of Communication \& Disorders, 14(4), 531-562.

Smith, A., \& Kelly, E. (1997). Stuttering: a dynamic, multifactorial model. In R. F. Curlee \& G. M. Siegel (Eds.), Nature and treatment of stuttering: new directions (pp. 204-207). Boston, MA: Allyn and Bacon.

Smith, K. A., Iverach, L., O’Brian, S., Mensah, F., Kefalianos, E., Hearne, A., \& Reilly, S. (2017). Anxiety in 11-year-old children who stutter: findings from a prospective longitudinal community sample. Journal of Speech, Language, and Hearing Research, 60(5), 1211-1222.

Throneburg, R. N., \& Yairi, E. (2001). Durational, proportionate, and absolute frequency characteristics of disfluencies. Journal of Speech, Language, and Hearing Research, 44(1), 38-51.

Trajkovski, N., Andrews, C., Onslow, M., Packman, A., O’Brian, S., \& Menzies, R. (2009). Using syllable-timed speech to treat preschool children who stutter: a multiple baseline experiment. Journal of Fluency Disorders, 34(1), 1-10.

Usler, E., Smith, A., \& Weber, C. (2017). A lag in speech motor coordination during sentence production is associated with stuttering persistence in young children. Journal of Speech, Language, and Hearing Research, 60(1),
51-61.

Van Borsel, J., Brepoels, M., \& De Coene, J. (2011). Stuttering, attractiveness and romantic relationships: the perception of adolescents and young adults. Journal of Fluency Disorders, 36(1), 41-50.

Wagovich, S. A., Hall, N. E., \& Clifford, B. A. (2009). Speech disruptions in relation to language growth in children who stutter: an exploratory study. Journal of Fluency Disorders, 34(4), 242-256.

Watts, A., Eadie, P., Block, S., Mensah, F., \& Reilly, S. (2017). Language skills of children during the first 12 months after stuttering onset. Journal of Fluency Disorders, 51, 39-49.

Yairi, E. (1981). Disfluencies of normally speaking two-year-old children. Journal of Speech, Language, and Hearing Research, 24(4), 490-495.

Yairi, E. (1982). Longitudinal studies of disfluencies in two-year-old children. Journal of Speech, Language, and Hearing Research, 25(1), 155-160.

Yairi, E. (1983). The onset of stuttering in two-and three-year-old children: a preliminary report. Journal of Speech and hearing Disorders, 48(2), 171-177.

Yairi, E., \& Ambrose, N. (1999). Early childhood stuttering I: persistency and recovery rates. Journal of Speech, Language, and Hearing Research, 42(5), 1097-1112.

Yairi, E., \& Ambrose, N. (2005). Early childhood stuttering: for clinicians by clinicians. Austin, TX: Pro-Ed.

Yairi, E., \& Ambrose, N. (2013). Epidemiology of stuttering: 21st century advances. Journal of Fluency Disorders, 38(2), 66-87.

Yairi, E., \& Lewis, B. (1984). Disfluencies at the onset of stuttering. Journal of Speech, Language, and Hearing Research, 27(1), 154-159. 


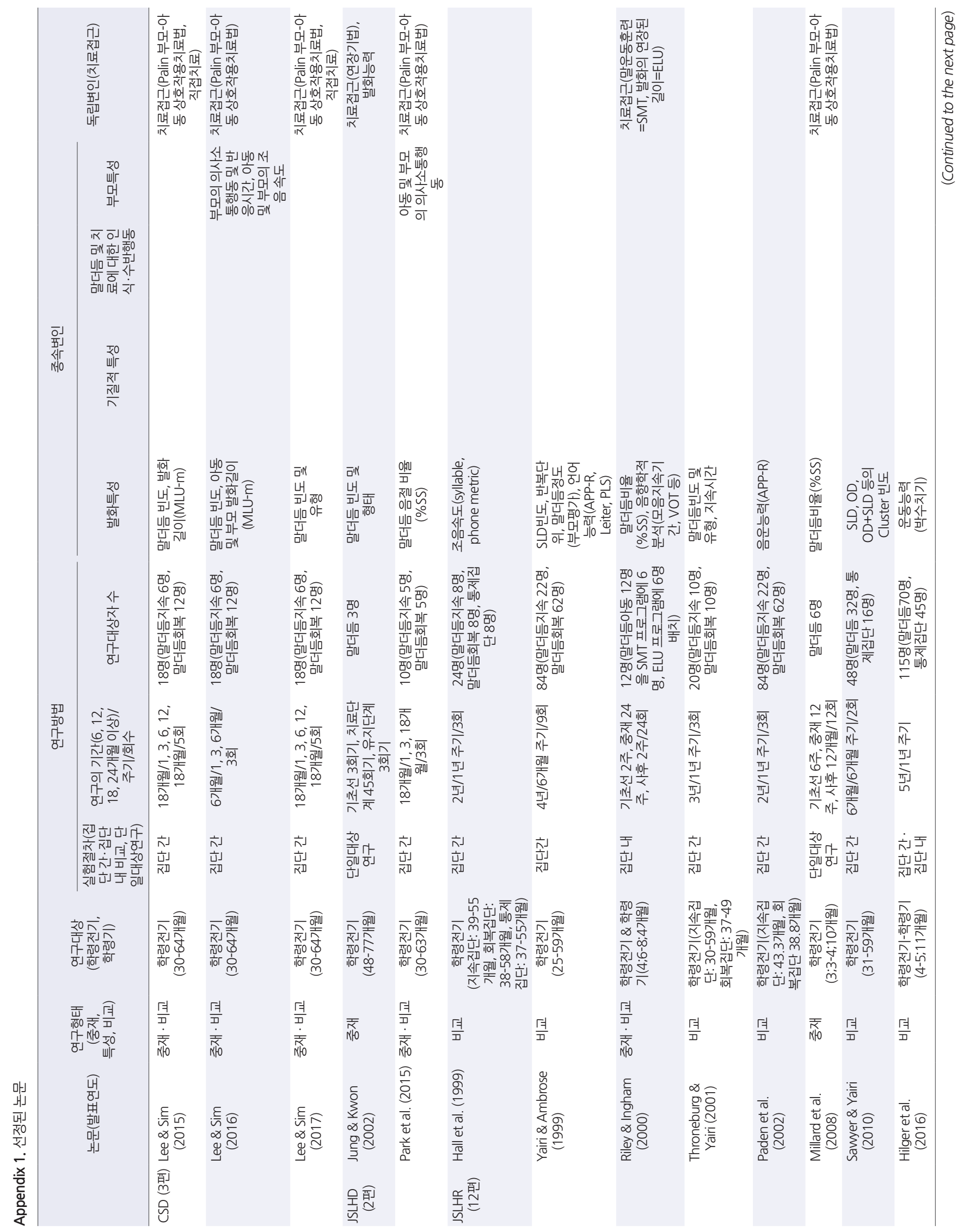




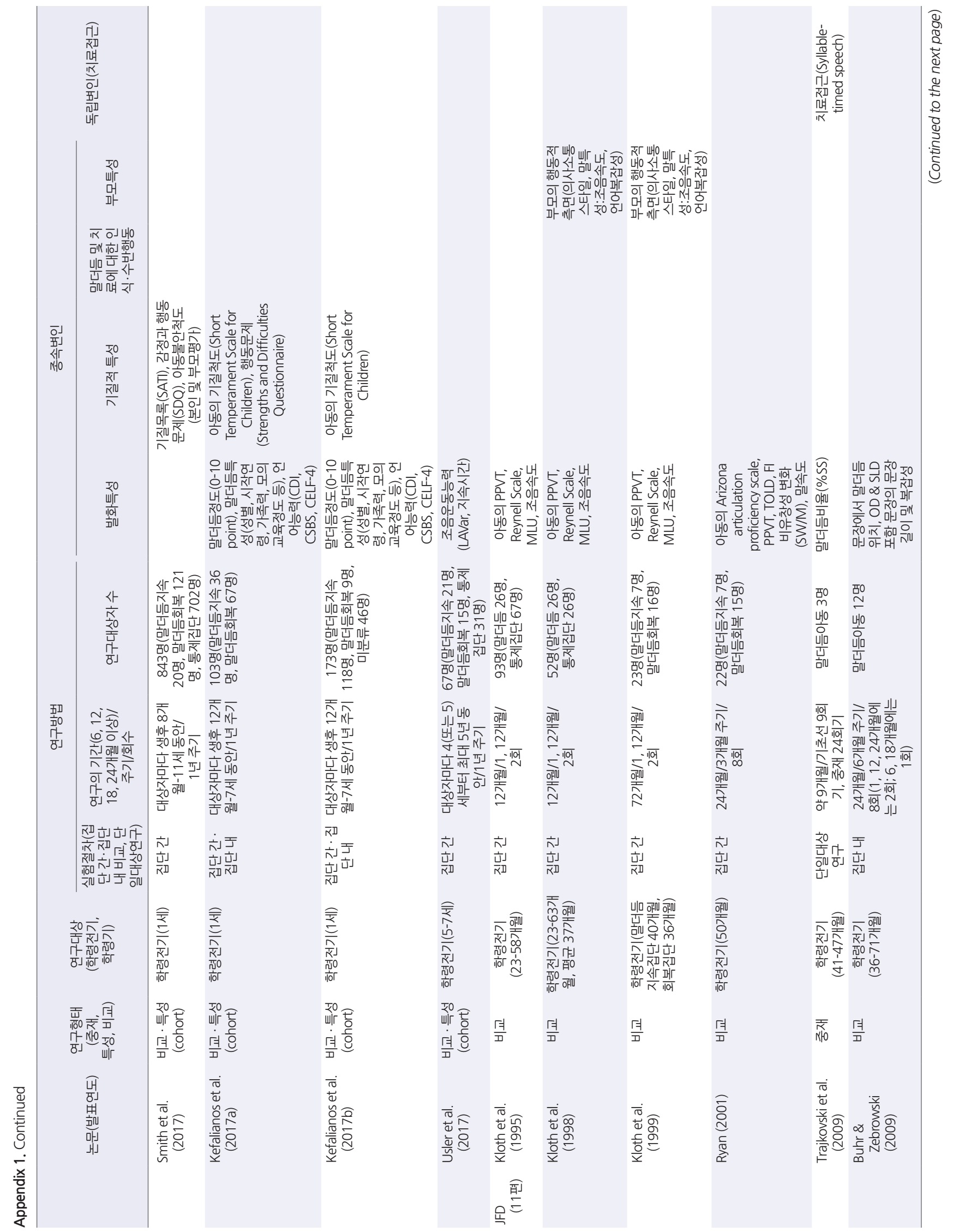




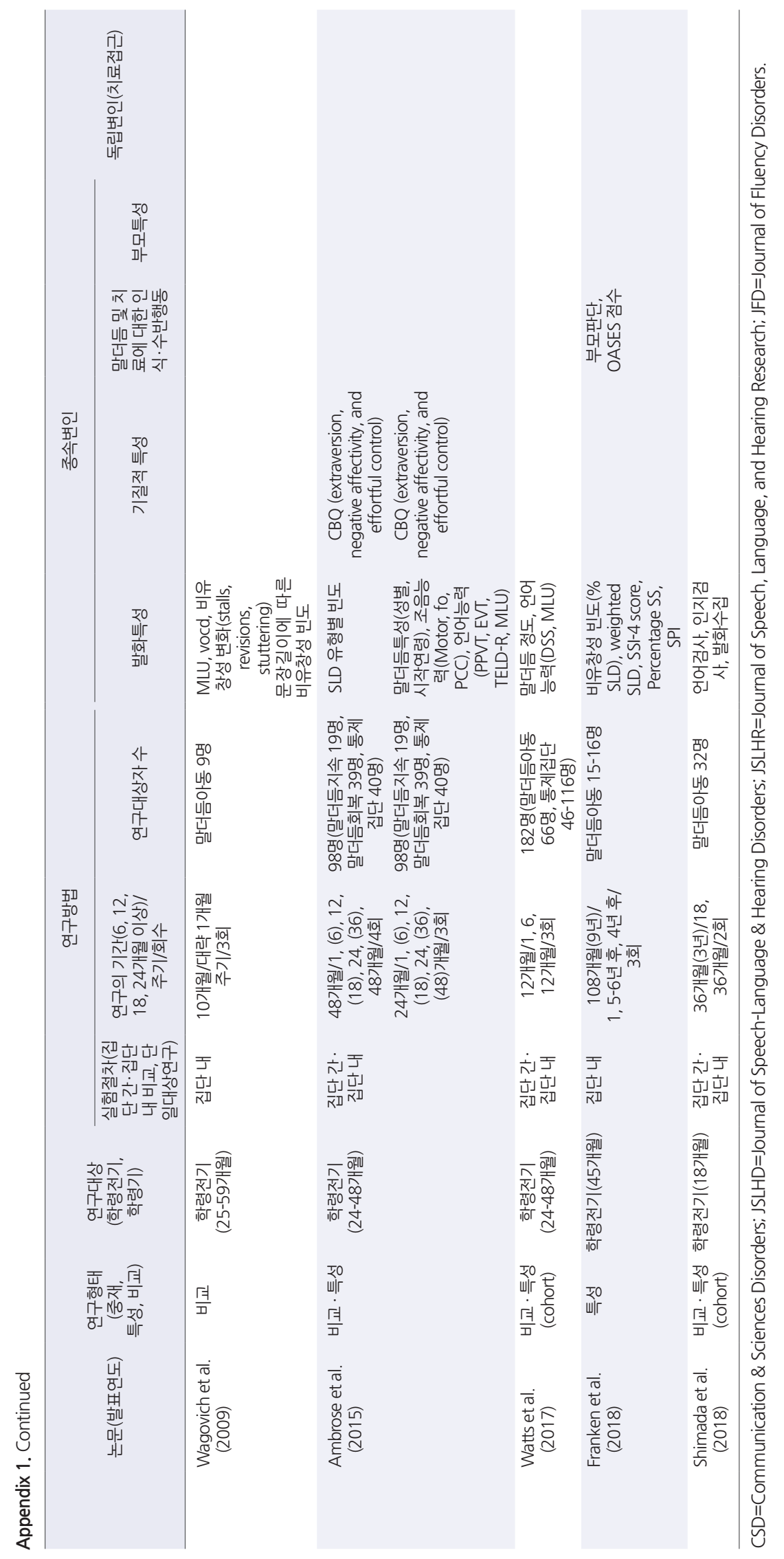




\section{국문초록}

\section{말더듬아동 종단연구에 관한 문헌연구}

이수복 1 박혜연 · 심현섭

${ }^{1}$ 우송대학교 언어치료청각재활학과, ${ }^{2}$ 이화여자대학교 대학원 언어병리학과

배경 및 목적: 초기 말더듬아동 대상의 종단연구들을 문헌연구 방식으로 고찰하여 종단연구와 SDUA 앱의 방향 및 필요성을 제시하 고자 하였다. 방법: CSD, JSLHD, JSLHR, 그리고 JFD에 등재된 1990-2018년 종단적 실험연구와 중재연구들을 고찰하였다. 결과: 선정 논문은 총 28편으로, CSD 3편, JSLHD 2편, JSLHR 12편, JFD 11편이었다. 연구형태는, 말더듬아동 회복집단과 지속집단 또는 일반아 동과 말더듬집단을 비교한 비교연구논문 12편(42\%), 중재연구논문 8편(29\%), 특성연구논문 8편(29\%)으로 나타났다. 연구대상은 1 세 미만 아동 연구가 3편(11\%), 2-6세 아동 연구가 25편(89\%)으로 나타났다. 연구방법은 중재·비교연구는 국내외 모두 집단 간(말더듬지 속, 회복집단) 비교연구가, 특성·비교연구는 국외에서 집단 간·집단 내(말더듬지속, 회복집단, 통제집단) 비교연구가 가장 많았으며, 시 간적 관점은 국내 연구는 18 개월간, 국외 연구는 24 개월간 연구가 가장 많았다. 연구대상자 수는 중재·비교연구에서 국내 연구는 $10-20$ 명, 국외 연구는 21-50명의 연구가 많았고, 국외의 특성연구에서는 100 명 이상의 연구가 $44 \%$ 로 나타났다. 종속변인은, 중재와 특성.비 교연구 모두 발화특성 연구가 대부분이었다. 논의 및 결론: 국내외 종단연구 대다수가 6개월 이상의 연구기간 동안 2가지 이상의 종속 변인을 최소 2 회 이상 측정하였고, 국내 연구는 18 개월 이상, 국외 연구는 24 개월 이상의 연구가 많았다. 이러한 결과는 증거중심 치료 의 요건을 갖춘 연구가 국내외에서 진행되고 있다는 것을 나타낸다. 또한, SDUA 앱은 아동의 말더듬 및 언어.말발달 특성, 그리고 부모 특성들을 측정하고, 종단 데이터 수집 및 분석을 위해 필요한 것으로 나타났다.

핵심어: 초기 말더듬아동, 유창성장애, 종단연구동향, 연구방법, 문헌연구

본 논문은 2018년 대한민국 교육부와 한국연구재단의 지원을 받아 수행된 연구임(No. NRF-2-2018-1600-001-1).

\section{참고문헌}

박혜연, 이수복, 심현섭(2015). 취학 전 말더듬아동의 회복여부에 따른 의사소통행동 특성. 언어치료연구, 24(4), 237-248.

신문자, 전희정, 이수복(2009). 유창성장애 연구의 최근동향: 치료를 중심으로. 언어청각장애연구, 14(4), 531-562.

이수복, 심현섭(2015). 초기 말더듬아동의 치료 후 말더듬회복 예측요인에 관한 종단연구: 발화길이를 중심으로. Communication Sciences \& Disor-

ders, 20(2), 189-201.

이수복, 심현섭(2016). 초기 말더듬아동의 치료효과 예측변인 연구. Communication Sciences \& Disorders, 21(2), 382-396.

이수복, 심현섭(2017). 취학 전 말더듬아동의 말더듬 치료시점별 진성비유창성 유형의 종단적 분석. Communication Sciences \& Disorders, 22(3), 540-549.

이현경, 이수복, 심현섭, 오인수(2016). 말더듬 청소년의 괴롭힘(bullying)에 관한 질적연구. 중등교육연구, 64(2), 417-450.

전희정, Nicoline Ambrose (2016). 말더듬이 지속된 아동과 회복된 아동의 비단어 따라말하기 능력. 언어치료연구, 25(4), 211-222.

정훈, 권도하(2002). 연장기법을 이용한 말더듬 치료 프로그램이 4-6세 말더듬 아동의 비유창성 개선에 미치는 효과. 언어치료연구, 11(1), 255-278.

\section{ORCID}

이수복(https://orcid.org/0000-0001-6942-4635); 박혜연(https://orcid.org/0000-0002-0994-6324); 심현섭(https://orcid.org/0000-0002-4710-3678) 